\title{
Pharmacological Management of Sexually Abused Adolescents with Comorbid PTSD and Bipolar Disorder: A Case Series
}

\author{
Gonca Celik¹, Aysegul Tahirog̃lu², Ayse Avcl ${ }^{3}$
}

\section{ÖZET:}

TSSB ve iki uçlu bozukluk ek tanısı olan cinsel istismara ug̃ramış ergenlerde farmakolojik tedavinin idaresi: Bir olgu serisi

Cinsel istismara ug̃ramış ergenlerde, travma sonrası stres bozuklug̃unun belirtileri iki uçlu bozukluk ve davranım bozuklug̃u gibi dig̃er bozuklukların belirtileriyle sıklıkla örtüșmektedir. Bu yazıda, beș olgunun klinik izlemi sırasında iki uçlu bozukluk ve travma sonrası stres bozuklug̃u ayıııc tanısında yaşanan güçı̈̈kler tartışlacaktır. Bu beș olgunun ayırıı tanısı ve seyri yatarak tedavi ve taburculuk dönemleri boyunca deg̃erlendirildi. Bu olguların tamamı aile üyesi veya yabancı bir erişkin tarafından fiziksel, duygusal ya da cinsel olarak istismar edilmiş idi. Olguların ikisinin ailesinde iki uçlu bozukluk öyküsü vardı. Bir olguda travma sonrası stres bozuklug̃u belirtileri için verilen antidepresan tedaviye bag̃lı manik atak oldu. Disosiyatif belirtiler ve irritabilitenin yaygın oldug̃u bu karışık klinik durumun tedavisinde ikinci kuşak antipsikotikler ve duygudurum düzenleyicileri kullanıldı. Travma sonrası stres bozuklug̃u ve iki uçlu bozukluk belirtilerinin çog̃u oldukça benzerdir. Bununla birlikte, bipolar bozuklug̃u olan çocuk ve ergenler cinsel istismar için artmış risk taşırlar veya bunun tersi de dog̃rudur. Klinisyenler bu olguların klinik ve farmakolojik yönetimi sırasında iki durumu da göz önüne almalıdırlar.

Anahtar sözcükler: ergen, travma sonrası stress bozuklug̃u, iki uçlu bozukluk, cinsel istismar

Journal of Mood Disorders 2012;2(3):133-8

\section{ABSTRACT:}

Pharmacological management of sexually abused adolescents with comorbid ptsd and bipolar disorder: a case series

Posttraumatic stress disorder (PTSD) symptoms in sexually abused adolescents often overlap with many other diseases, such as conduct disorder and bipolar disorder (BD). In this paper, the difficulties encountered in making the differential diagnosis of BD and PTSD will be discussed with clinical outcomes of five cases. The follow-up findings and differential diagnosis of five cases were evaluated throughout their hospitalization and after discharge. All of these cases have been abused physically, sexually or emotionally by their family members or adult strangers. Two cases had a positive family history of BD. One case switched to manic state due to antidepressant treatment prescribed for PISD symptoms. Dissociative symptoms and irritability were common and atypical antipsychotics and mood stabilizers have been used for the treatment of these mixed clinical states. Many symptoms of PTSD and $\mathrm{BD}$ are very similar. Moreover, children and adolescents with BD are under greater risk for sexual abuse or vice versa are also correct. Clinicians should take into consideration both clinical states during clinical and pharmacological management of these patients.

Key words: adolescent, posttraumatic stress disorder, bipolar disorder, sexual abuse

Journal of Mood Disorders 2012;2(3):133-8
${ }^{1} \mathrm{MD}$, Assistant Professor of Child and Adolescent Psychiatry, Cukurova University Faculty of Medicine, Child and Adolescent Psychiatry Department, Balcali, Adana-Turkey ${ }^{2} \mathrm{MD}$, Associate Professor of Child and Adolescent Psychiatry, Cukurova University Faculty of Medicine, Child and Adolescent Psychiatry Department, Balcali, Adana-Turkey Psychiatry Department, Balcali, Adana-T
${ }^{3}$ MD, Professor of Child and Adolescent Psychiatry, Cukurova University Faculty of Psychiatry, Cukurova University Faculty of
Medicine, Child and Adolescent Psychiatry Department, Balcali, Adana-Turkey

Yazıșma Adresi / Address reprint requests to: Assistant Professor Gonca Çelik, Cukurova Univercity Faculty of Medicine Child and Adolescent Psychiatry Department Balcali 01330, Adana-Turkey

Telefon / Phone: +90-322-338-6060

Elektronik posta adresi / E-mail address: goncagulcelik@gmail.com

Kabul tarihi / Date of acceptance: 20 Ag̃ustos 2012/ August 20, 2012

Bag̃ıntı beyanı

G.C., A.T., A.A.: Yazarlar bu makale ile ilgili olarak herhangi bir çıkar çatıșması bildirmemistir.

Declaration of interest:

G.C. A.I. A.A.: The authors reported no conflict of interest related to this article.

\section{INTRODUCTION}

Among bipolar patients, rates of comorbid posttraumatic stress disorder (PTSD) and suicidal attempts were reported as $16.0 \%$ and $25-50 \%$, respectively $(1,2)$. It has been shown that the adults with bipolar disorder (BD) have an increased rate of sexual or physical abuse history at earlier ages which is known to be associated with greater prevalence of rapid cycling, suicidal attempts, co-morbid anxiety disorders, PTSD, substance use disorders, and personality disorders (3). Additionally, there may be considerable overlap of symptoms of BD and PTSD such as irritability, sleep disturbances, aggressive behaviors, and increased sexual behaviors.

Genetic variations in brain function may mediate the pathological response to trauma and the vulnerability to the effects of stress. It has been suggested that genetic 


\begin{tabular}{|c|c|c|c|c|c|}
\hline & PISD symptoms & Depressive Symptoms & Manic Symptoms & Mania induced by & BPD in Family \\
\hline Case-1 & Hyperarousal & Suicide attempt & $\begin{array}{l}\text { Hyper-sexuality, } \\
\text { grandiosity }\end{array}$ & Fluoxetine & + \\
\hline Case-2 & $\begin{array}{l}\text { Flashback, } \\
\text { hyperarousal, } \\
\text { nightmare }\end{array}$ & - & $\begin{array}{l}\text { Talkativeness, } \\
\text { hyper-sexuality, } \\
\text { psychomotor agitation }\end{array}$ & - & + \\
\hline Case-3 & - & $\begin{array}{l}\text { Crying, guilty, } \\
\text { depressive mood, } \\
\text { suicidal ideas }\end{array}$ & $\begin{array}{l}\text { Hyper-sexuality, } \\
\text { agitation, pressed } \\
\text { speech, hallucination, } \\
\text { insomnia }\end{array}$ & Escitalopram & - \\
\hline Case-4 & $\begin{array}{l}\text { Nightmare, } \\
\text { avoidance, } \\
\text { flashback }\end{array}$ & - & $\begin{array}{l}\text { Elevated mood, } \\
\text { hyper-sexuality, } \\
\text { delusions }\end{array}$ & - & - \\
\hline Case- -5 & $\begin{array}{l}\text { Nightmare, } \\
\text { flashback, } \\
\text { avoidance, } \\
\text { hyperarousal }\end{array}$ & - & $\begin{array}{l}\text { Accelerated thought, } \\
\text { insomnia, hyper } \\
\text {-sexuality, elevated } \\
\text { mood, delusions }\end{array}$ & - & + \\
\hline
\end{tabular}

factors are associated with tendency to PTSD and depression $(4,5)$ and, there is evidence of a gene-byenvironment interaction, in which an individual's response to environmental events are moderated by genetic structures $(6,7)$. In addition, bipolar adolescents with a history of any abuse/neglect have been more likely to have family history of mood disorders, substance abuse, and conduct disorder in their first-degree relatives when compared with non-abused group (8).

Among children with $\mathrm{BD}$, the most commonly seen symptoms include irritability, mood lability, sleep disturbances, anger, impulsiveness and agitation; however, psychosis and increased sexual behaviors have been reported much less than others (9). Leverich et al. have observed that physically abused patients have reported an increased suicidal ideation during their manic episode, whereas, sexually abused patients reported it during their depressive episode (10). Additionally, current findings in the etiology of major depression (MD) revealed that they were strong candidates for PTSD and vice versa (11). A similar hypothesis may account for the etiology of co-morbid BD and PTSD. Sher et al. suggested the "post traumatic mood disorder" model to describe the same clinical concept. (12). Symptoms of BD are often misdiagnosed as unipolar depression prior to a patient's first bipolar diagnosis. In other words, one-third of bipolar patients receive antidepressant monotherapy because of misdiagnosis of unipolar depression (13).

In this report, difficulties encountered in differentiating the diagnosis and managing pharmacologically BD patients will be discussed. Besides, clinical features of five adolescents with PTSD diagnosis will be presented.

\section{METHODS}

All cases were treated as inpatients of the residential treatment center for adolescent female victims of sexual abuse. This center is the first residential institution in Turkey and is specialized for the care of sexually abused cases. Psychiatric diagnoses of the cases were made according to DSM-IV-TR (14). Long term monitoring of them was possible since their social and psychiatric care were provided approximately for 6-8 months in the center. Clinical characteristics of the cases are shown in Table 1.

\section{CASE 1}

A 16 years old girl who was abused emotionally by her parents has had suicidal attempts. Her sister also had a history of completed suicide. She was hospitalized in the 
residential treatment center because of her increased sexually risky behaviors, insomnia, agitation, suicidal thoughts and anhedonia. She was diagnosed as PTSD and depressive disorder according to DSM-IV-TR criteria at her first psychiatric assessment. Initially, she was put on fluoxetine $20 \mathrm{mg} /$ day treatment. In her second week of treatment she developed manic symptoms including grandiose thoughts, elevated mood, psychomotor agitation, talkativeness, inappropriate sexual behaviors, insomnia, and paranoid delusions that led the preliminary diagnosis of substance/medication induced mania. Quetiapine $300 \mathrm{mg} /$ day was started and this treatment was continued throughout nine months period of her hospitalization. She was then discharged in a fully remitted state. After quitting her medications with her own decision she experienced a manic excitation. She run away from her home and had many risky sexual intercourses with typical manic symptoms during this episode. Since she developed a second manic episode poly-pharmacy was preferred and a combination of olanzapine $20 \mathrm{mg} /$ day and lithium $900 \mathrm{mg} /$ day treatment was initiated. Full remission was again achieved at the second month of her treatment which was held in an outpatient setting. No other manic episode was observed during her one year period of follow-up visits.

\section{CASE 2}

A 16 years old girl was diagnosed with Bipolar-I disorder, manic episode. Her symptoms included truancy, inappropriate sexual behavior, talkativeness, psychomotor agitation, somatic complaints, and persecutory delusions. She thought that her friends were watching and planning to kill herself. These symptoms have begun two years ago. She was unable to achieve her academic goals. Eventually, she dropped out of the school. In her family history she also had an uncle with BD-1. Her parents were unable to control her behavior and to provide regular maintenance treatment that caused their physical abuse to her. After escaping from her home she became the victim of a sexual abuse by verbal interferences and touching by adult strangers. She was accused by her parents for her symptoms, and they had severe anxiety about the potential risk of sexual abuse of her. Combination treatment with olanzapine $20 \mathrm{mg} /$ day and lithium $900 \mathrm{mg} /$ day was initiated, her symptoms improved significantly at her second month of treatment, and then she was discharged.

\section{CASE 3}

A 14 years old girl, physically abused by her mother, had run away from home and school. She had insomnia and increased sexually risky behaviors. When she was hospitalized, she had depressive symptoms such as ever so often crying, depressive mood, suicidal ideas, and guilt feelings. Her diagnosis at her first assessment was conduct disorder and depressive disorder according to DSM-IVTR. Escitalopram $10 \mathrm{mg} /$ day was prescribed. In the second week of this treatment, her depressive symptoms had decreased but on the other hand increased insomnia, agitation and visual hallucinations were observed. Her diagnosis was considered as substance/medication induced mania, then escitalopram treatment was discontinued and aripiprazole $20 \mathrm{mg} /$ day was given. Familial relationships were evaluated via family therapy and she was discharged to her home after achieving full remission. The case was not followed up as an outpatient, because she quitted the medication by herself. She had run away from her home again during a new episode, and she could not be found by her parents and child protection services.

\section{CASE 4}

A 17 years old girl was married forcibly and illegally with coercion of her parents. She had extramarital sexual intercourses during this marriage. When her husband became aware of her affairs, he had tried to kill her and then she had run away from her home. Her increased risky sexual behaviors and sexual intercourses continued through a few days, while she was out of home. She had a labile mood, inconvenient laughing during the first psychiatric examination and, she had nightmares, anxiety symptoms, avoidance and flashbacks about her marriage, too. Initially, she had been diagnosed as conduct disorder and PTSD according to DSM-IV-TR criteria and accepted to our residential treatment center as an inpatient. However, at the follow up, the diagnosis was revised as BPD because of elevated mood, increased risky sexual behavior, and delusional thoughts. Lithium $900 \mathrm{mg} /$ day and aripiprazole $20 \mathrm{mg} /$ day was initiated for her 
treatment. Her symptoms improved significantly at the end of the first month of this treatment. Meanwhile, her marriage was recalled by the Child Court, because a marriage before 18 years old age was illegal according to the Turkish Laws. To improve relationships and communications, family therapy was planned. She was discharged from inpatient treatment and she returned to her home after achieving full remission.

\section{CASE 5}

A 17 years old girl was hospitalized for psychiatric evaluation. She had run away from her home when she was 15 years old and, she was abused sexually by three adult strangers. Additionally, she was very impulsive and had difficulty in anger management since early childhood and, she had met the criteria of Attention Deficit and Hyperactivity Disorder according to DSM-IV criteria. In her first psychiatric examination, she had accelerated thought and speech, flight of ideas, insomnia, increased risky sexual risky behavior, elevated mood and paranoid delusions. Also, she had symptoms related to PTSD including avoidant behaviors, nightmares and flashbacks about her past traumatic events. Additionally, her mother had also BPD. She had been neglected and abused physically, emotionally by her mother since early childhood years. She was diagnosed as BPD and co-morbid PTSD. Aripiprazole $30 \mathrm{mg} /$ day and lithium $900 \mathrm{mg} /$ day was initiated. Because of her aggressive and destructive behaviors, a depot antipsychotic (monthly administered zuclopenthixol) was added to this treatment. She was hospitalized through one year in our residential treatment center. Her symptoms partially improved, but there was no full remission. When she was discharged from inpatient ward she had hypo-manic symptoms and exhibited less severe PTSD symptoms during the following two years.

\section{DISCUSSION}

Read et al. suggested that traumatic experiences might negatively affect the early brain development. They maintained the hypothesis so called as "Traumagenic Neurodevelopmental Model” (15). Specifically, hyperactivity of the hypothalamic-pituitary-adrenal axis can lead to functional alterations in central dopaminergic and serotonergic systems. This model might explain why bipolar children with a history of sexual abuse are more likely to present psychotic symptoms as compared to those without this history (16). Similarly, all the cases involved in this study, had psychotic symptoms, such as delusions or hallucinations. It was reported that none of the subjects reporting atypical psychotic symptoms went on to develop a classic psychotic illness even after 2 years follow-up (17). In accordance with this report, our cases developed no hallucination or psychotic symptom, with an exception of the first manic-state in the early hospitalization period.

These cases had significantly higher rates of sexual abuse history and dissociative symptoms and, were significantly more likely to receive a diagnosis of PTSD or depressive disorder than the adolescents with schizophrenia or BPD $(2,17)$. Additionally, a positive family history of BPD among these cases was more compatible to diagnose them as a mood disorder rather than another psychiatric disorder.

Bipolarity may increase the vulnerability to sexual, physical or emotional abuse or vice versa. Our cases have had also many behavioral and emotional problems since earlier ages even before the diagnosis of BPD was made; the most of the cases have been abused and/or neglected by their families because of their aggressive and destructive behaviors. All of them have had increased risky sexual behavior, which have been related to $\mathrm{BPD}$, so they have also had increased risk for sexual abuse as suggested by previous reports (9). Clinicians should be aware of the suicidality and hyper-sexuality symptoms and other externalizing behaviors, even though sometimes these behaviors are considered to be developmentally appropriate for adolescents. These symptoms may also be antecedents to BPD. Dissociative hallucinations, hyper-sexuality and neurovegetative symptoms overlap in both PTSD and BPD and, in several clinical conditions, such as borderline personality disorder, as well. PTSD associates with a poorer outcome in BPD, as assessed by their lower likelihood to recover, elevated proportion of rapid cycling periods, increased risk of suicide attempts and a worse quality of life (18)

Antidepressants can be useful to treat the depressive symptoms of PTSD and BPD, but they should be used carefully because of manic excitation, impulsivity, aggression, and labile mood tendency $(19,20)$. Similarly, antidepressants were used for the treatment of avoidance 
symptoms of PTSD in two of our cases, but these medications were stopped because of manic excitation.

Chronic levels of irritability, aggression, and hyperarousal often appear to be hypomanic or manic episodes. Mood stabilizers, such as divalproex-sodium, lithium and carbamazepine have been found to be effective in the treatment of BPD $(21,22)$. In this study, algorithms and results of the medical treatments were in accordance with the previous reports $(17,23,24)$; antipsychotic drugs and/ or mood stabilizers were useful in the treatment of all of our cases.

There are some limitations of this study, such as the long observation period because of hospitalization in residential center. First, our information about their premorbid functionality and mental health was based on the information we received from their parents, social reporters or themselves. Since most of the parents neglect their children they could not be aware of mental health status of them. Second, bipolar diagnosis after the manic switch during SSRI treatment may be controversial. However, this phenomenon is called as BPD-3 and, is currently suggested for DSM-V system $(19,20)$. In other words, as many patients with BPD begin a cycle into mania with a pre-manic, hypo-manic or a depressive episode, it is possible that the application of antidepressant treatment to such patients emerges the cycle and that the

\section{References:}

1. Otto MW, Perlman CA, Wernicke R, Reese HE, Bauer MS. Posttraumatic stress disorder in patients with bipolar disorder: a review of prevalence, correlates and treatment strategies. Bipolar Disord 2004; 6:470-479.

2. Chen Y, Dilsaver S. Lifetime rates of suicide attempts among subjects with bipolar and unipolar disorders relative to subjects with other Axis I disorders. Biol Psychiatr 1996; 39:896-899.

3. Jamison KR. Suicide and bipolar disorder. J Clin Psychiatry 2000; 61:47-51.

4. Yehuda R. Biological factors associated with susceptibility to posttraumatic stress disorder. Can J Psychiatry 1999; 44:34-39.

5. Sher L, Greenberg BD, Murphy DL, Rosenthal NE, Sirota LA, Hamer DH. Pleiotropy of the serotonin transporter gene for seasonality and neuroticism. Psychiatr Genet 2000; 10:125-130.

6. Lesch KP. Gene-environment interaction and the genetics of depression. J Psychiatry Neurosci 2004; 29:174-184.

7. Caspi A, Sugden K, Moffitt TE, Taylor A, Craig IW, Harrington H, McClay J, Mill J, Martin J, Braithwaite A, Poulton R. Influence of life stress on depression: moderation by a polymorphism in the 5-HTT gene. Science 2003; 301:386-389. resulting hypomania or mania is not an antidepressant induced effect, but this may be related to the natural course of the illness. According to the results of EPIDEP study, depressive temperament and bipolar family history were more commonly seen among those switched to hypomania during antidepressant treatment $(19,25)$.

In conclusion, symptoms of PTSD and mood disorders may overlap. Consequently, sexual abuse and PTSD may be often miss-diagnosed as BPD or both of them may be described as single dysregulation syndrome (26). Similarly, children and adolescents with BPD have also greater risk for sexual abuse and, their BPD may be often miss-diagnosed as PTSD. Clinicians must evaluate both clinical conditions during pharmacological management. When starting SSRI treatment, family history of BPD or premorbid psychiatric history should be taken thoroughly. Afterwards, any mood stabilizer could be added to SSRI treatment regimen. To gain a more comprehensive understanding of the process between PTSD and mood disorders future clinical studies are needed.

\section{Acknowledgement}

The authors would like to thank other staffs of residential treatment center, especially health and social workers.

8. Baldassano CF, Marangell LB, Gyulai L, Nassir Ghaemi S, Joffe H, Kim DR, Sagduyu K, Truman CJ, Wisniewski SR, Sachs GS, Cohen LS. Gender differences in bipolar disorder: retrospective data from the first 500 STEP-BD participants. Bipolar Disord 2005; 7:465-470.

9. Faedda GL, Baldessarini RJ, Glovinsky IP, Austin NB. Pediatric bipolar disorder: phenomenology and course of illness. Bipolar Disord 2004; 6:305-313.

10. Leverich GS, McElroy SL, Trisha Suppes T, Paul E. Keck, Denicoff KD, Nolen WA, Altshuler LL, Rush AJ, Kupka R, Frye MA, Autio KA, Post RM. Early Physical and Sexual Abuse Associated with an Adverse Course of Bipolar Illness. Biol Psychiatry 2002; 51:288-297.

11. Koenen KC, Fu QJ, Ertel K, Lyons MJ, Eisen SA, True WR, Goldberg J, Tsuang MT. Common genetic liability to major depression and posttraumatic stress disorder in men. J Affect Disord 2008; 105:109-115

12. Sher L. The concept of post-traumatic mood disorder. Med Hypotheses 2005; 65:205-210.

13. Ghaemi SN, Sachs GS, Chiou AM, Pandurangi AK, Goodwin FK. Is bipolar disorder still underdiagnosed? Are antidepressants overutilized? J Affect Disord 1999; 52:135-144. 
14. American Psychiatric Association. Diagnostic and statistical manual of mental disorders. 4th ed. Text revision Washington (DC): American Psychiatric Association; 2000.

15. Read J, Van Os J, Morrison AP, Ross C. Childhood trauma, psychosis and schizophrenia: a literature review with theoretical and clinical implications. Acta Psychiatr Scand 2005; 112:330-350.

16. Soledad Romero S, Birmaher B, Axelson D, Goldstein T, Goldstein BI, Gill MK, Iosif AM, Strober MA, Hunt J, Esposito-Smythers C, Ryan ND, Leonard H, Keller M. Prevalence and Correlates of Physical and Sexual Abuse in Children and Adolescents with Bipolar Disorder. J Affect Disord 2009; 112: 144-150.

17. Hlastala SA, McClelan J. Phenomenology and diagnostic stability of youths with atypical psychotic symptoms. J Child Adolesc Psychopharmacol 2005; 15:497-509.

18. Quarantini LC, Miranda-Scippa A, Nery-Fernandes F, AndradeNascimento M, Galvão-de-Almeida A, Guimarães JL, Teles CA Netto LR, Lira SB, de Oliveira IR, Post RM, Kapczinski F, Koenen KC. The impact of comorbid posttraumatic stress disorder on bipolar disorder patients. J Affect Disord 2010; 123:71-76.

19. Chun BJDH, Dunner DL. A review of antidepressant-induced hypomania in major depression: suggestions for DSM-V. Bipolar Disord 2004; 6:32-42.

20. Akiskal HS. Validating antidepressant-associated hypomania (Bipolar III): a systematic comparison with spontaneous hypomania (Bipolar II). J Affect Disord 2003; 73:65-74.
21. Marshall RD, Stein DJ, Leibowitz MR, Yehuda R.Apharmacotherapy algorithm in the treatment of posttraumatic stress disorder. Psychiatric Annals 1996; 26:217-226.

22. Kavoussi RJ, Coccaro EM. Divalproex sodium for impulsive aggressive behavior in patients with personality disorder. J Clin Psychiatry 1998; 59:676-680.

23. Aichhorn W, Stuppack C, Kralovec K, Yazdi K, Aichhorn M, Haussmann A. Child and adolescent bipolar disorder. Neuropsychiatr 2007; 21:84-92.

24. Ulloa RE, Birmaher B, Axelson D, Williamson DE, Ryan ND, Bridge J, Baugher M. Psychosis in a pediatric mood and anxiety disorders clinic: phenomenology and correlates. J Am Acad Child Adolesc Psychiatry 2000; 39:337-345.

25. Akiskal HS, Akiskal KK, Lancrenon S, Hantouche EG, Fraud JP, Gury C, Allilaire JF. Validating the bipolar spectrum in the French National EPIDEP Study: overview of the phenomenology and relative prevalence of its clinical prototypes. J Affect Disord 2006; 96:197-205.

26. Ayer L, Althoff R, Ivanova M, Rettew D, Waxler E, Sulman J, Hudziak J. Child Behavior Checklist Juvenile Bipolar Disorder (CBCL-JBD) and CBCL Posttraumatic Stress Problems (CBCLPTSP) scales are measures of a single dysregulatory syndrome. J Child Psychol Psychiatry 2009; 50:1291-1300. 